\title{
Discipline and Publish: A Rallying Call for the Infliction of Gynaecological Justice
}

\author{
Joseph Miller* \\ University of the Third Degree, Australia
}

\section{SHORT COMMUNICATION}

The field of gynaecology is at a crossroads, and if our field is to cross the road, it must engage in self-reflection, like a mirror gazing into a mirror. As we leave the mirror of the field of gynaecology gazing into itself at the crossroads, it is time that the rest of us discussed the enemy within. It is time that we discussed how to expunge the enemy within from the field, at the crossroads [1].

\section{The enemy within}

Over the past decade, the field of gynaecology has become overrun with vermin. These vermin look and act like academic publishers, but their presence is problematic insofar as it is predicated on non-standard conceptions of reality. While equally as valid as standard conceptions of reality, non-standard conceptions of reality make it impossible to form predictions or duplicate findings [2]. Naomi Sims sums up the current sad state of things below (Table 1).

While the contents of Table 1 may be unsurprising in 2019, they fly in the face of the ACOG's Guidelines on the Essential Properties of a Gynecological Journal 2019 and create a situation in which surgeons may find themselves swallowing cannulas in an effort to 'scare away orgones' [3]. The contents of Figure 1 should come as no surprise.

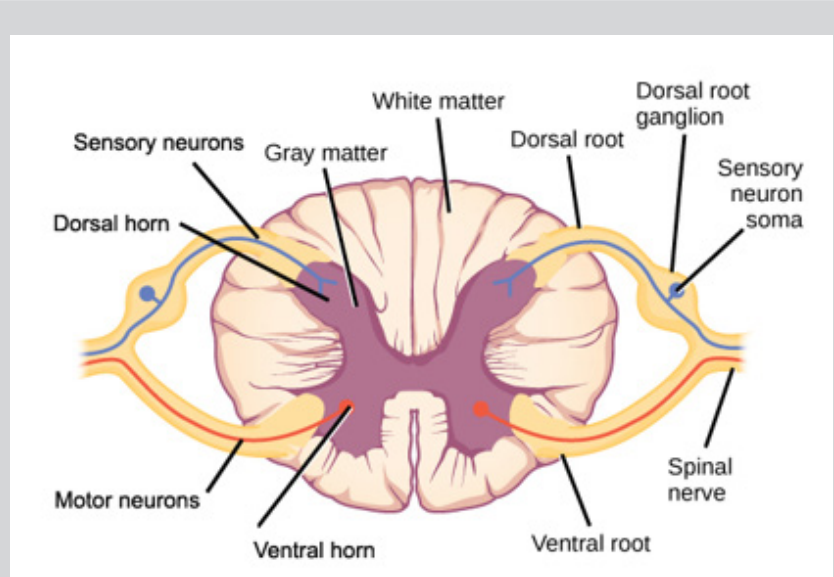

Figure 1: The sort of thing you could get away with calling an 'Ovary' in the Open Access Journal of Biomedical Science.

\section{A modest proposal}

As practitioners of the world's greatest art, surgeons are familiar with the process of removing foreign bodies from the stomach. It is time that we extended that skill into new areas and cut out the vermin of fabrication from the crossroads at the heart of the field of gynaecology. Further research funding should be directed towards finding the people behind the open access journal of biomedical science and flying them to the Hague [4].
Quick Response Code:

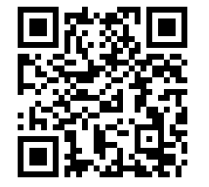

Address for correspondence: Joseph Miller, University of the Third Degree, Australia

Received: August 28, 2019 Published: September 23, 2019

How to cite this article: Joseph Miller, Discipline and Publish: A Rallying Call for the Infliction of Gynaecological Justice. 2019 - 1(2) OAJBS.ID.000105. DOI: 10.38125/OAJBS.000105 
Table 1: Excerpt from a table in 'Caytyves and rank corruption at the hearte of our professione' Sims [4].

\begin{tabular}{|c|c|c|c|}
\hline Journal title & $\begin{array}{c}\text { Advisability of forming } \\
\text { predictions based on the } \\
\text { content of this journal }\end{array}$ & $\begin{array}{c}\text { Possibility of replicating } \\
\text { research presented in this } \\
\text { journal }\end{array}$ & $\begin{array}{c}\text { Probability that this journal } \\
\text { will contain stories about } \\
\text { giant railway guns }\end{array}$ \\
\hline Human Reproduction Update & High & Not impossible & Low \\
\hline $\begin{array}{c}\text { American Journal of Obstetrics } \\
\text { and Gynecology }\end{array}$ & High & Not impossible & Fot impossible \\
\hline Fertility and Sterility & Not inconsiderable & Low & Not low \\
\hline $\begin{array}{c}\text { Open Access Journal of } \\
\text { Biomedical Science }\end{array}$ & Low & Low & Extremely high \\
\hline $\begin{array}{c}\text { Gynecology \& Reproductive } \\
\text { Health (SciVision Publishers) }\end{array}$ & $\begin{array}{c}\text { On par with the advisability of wearing } \\
\text { gazelle-meat trousers in the lion } \\
\text { enclosure }\end{array}$ & .
\end{tabular}

\section{REFERENCES}

1. ACOG (2019) Guidelines on the essential properties of a Gynaecological Journal. Rockville, Mary Land, USA.

2. Baker EM (2019) Science and health... and don't trust the Open Access Journal of Biomedical Science. Journal of Dark Thoughts 34(2): 45354566
3. Blackheath S (2018) Why I don't trust the Open Access Journal of Biomedical Science as far as I can throw it. Clinical Reflections 1(5): 34 36.

4. Sims N (2019) Caytyves and rank corruption at the hearte of our professione. Annals of Gynecologick Lore 23(2): 102-106. 